\title{
FULL-SCALE MODEL VOZOVKY PRO ZKOUŠENÍ KONSTRUKCÍ NETUHÝCH VOZOVEK NEJEN Z RECYKLOVANÝCH MATERIÁLŮ
}

\author{
FULL-SCALE PAVEMENT MODEL FOR TESTING OF NON-RIGID \\ PAVEMENT STRUCTURES NOT ONLY FROM RECYCLED MATERIALS
}

Karel Spies ${ }^{*}, 1$

spies.k@fce.vutbr.cz

${ }^{1}$ Vysoké učení technické v Brně, Fakulta stavební, Veveří 331/95 Brno Abstrakt

Použivání recyklátů do konstrukčních vrstev vozovek se pomalu stává hlavním tématem při výstavbě pozemních komunikací. Zkoušení a použití těchto materiálů v konstrukcích vozovek však může být odlišné oproti vozovkám z nových materiálů. Proto tento príspěvek pojednává o problematice použivání recyklátů, a to zejména asfaltových, v konstrukčních vrstvách vozovek.

V hlavní části se článek zaměruje na zkoušení celého vozovkového souvrství pomocí Full-Scale modelu. V další části př́spěvku jsou vysvětleny důvody pro zavedení tohoto modelu při zkoušení vozovek a je shrnuta vybraná zahraniční literatura o dané problematice. V závěru článku jsou pak uvedeny možné budoucí metody, které by mohly být využity ke zpřesnění získaných výsledků měřní a přibližzení modelu ke skutečným podmínkám.

\section{Klíčová slova}

Full Scale model vozovky, recyklované materiály, konstrukce vozovky, instrumentace modelu

\begin{abstract}
The utilisation of recycled materials in pavement construction layers is slowly becoming a major issue in road construction. However, the testing and use of these materials in pavement structures may be different from pavements made of new materials.

Therefore, this paper discusses the issue of using recycled materials, especially reclaimed asphalt, in pavement structures. In the main part, the paper focuses on testing the entire road structure using a Full-Scale model. The next part explains the reasons for implementing this model in pavement testing and summarizes the selected foreign literature on the subject. The paper then concludes with possible future methods that could be used to improve the obtained measurement results and to bring the model closer to the actual conditions.
\end{abstract}

Key words

Full Scale Pavement Model, Recycled Materials, Pavement Construction, Model Instrumentation

\section{1 ÚVOD}

Recyklace se v dnešní době stává jedním z nejčastěji používaných pojmů na světě, a proto není divu, že již pronikl i do oblasti silničního stavitelství. Využívání recyklovaných materiálů v konstrukcích pozemních komunikací, a to od podloží až po krytové vrstvy, se stává stále častějším, a to jak z důvodu nedostatku kvalitních surových materiálů nebo kvůli ochraně životního prostředí.

Vzhledem $\mathrm{k}$ tomu, že na rozdíl od surových materiálů je kvalita a složení každého recyklátu odlišné a často neznámé, je aktuálně obtížné obsáhnout jejich možnosti použití pouze pomocí předpisů a norem. Zároveň není vždy možné na těchto materiálech provádět funkční či empirické zkoušky jako u nových materiálů, respektive jejich výsledky nemusí být vždy dostatečně věrné. A právě díky výše uvedeným důvodům je potřeba zavést další doplňující zkušební postup, který prokáže či vyloučí použití vybraného materiálu, respektive daného složení vrstev, $\mathrm{v}$ konstrukci vozovky.

Tento proces by probíhal ve zkušebním zařízení, které zjednodušeně simuluje reálné zatěžovací podmínky ve vozovce, a průběžně snímá základní údaje o aktuálním stavu všech konstrukčních vrstev vozovky (teplota, průhyb 
vrstev, napětí v závislosti na hloubce, popř. vlhkost či posun vrstev). Tato naměřená data by pak byla porovnána s daty naměřenými na odpovídající vzorové vozovce navržené dle katalogu vozovek v TP 170, dodatek 1 [1]. Jednalo by se tak o víceméně porovnávací metodu, která by určila, zda daná skladba vozovky dokáže stejně, méně či více odolávat zatížení než referenční skladba vozovky, skládající se pouze ze surových materiálů.

\section{PřEHLED POUŽÍVANÝCH ZAŘÍZENÍ}

Tato kapitola shrnuje využívání Full-Scale modelů, respektive jejich obdob, ve světě. Většina z těchto modelů či zkušebních míst se liší od zkušebního modelu vytvářeného na Ústavu pozemních komunikací, a proto jsou zde uvedeny pouze základní typy. Rozdíly spočívají převážně v typu a způsobu zatěžování, umístění modelu, skladbě vrstev nebo ve sledovaných hodnotách. Full-Scale model vozovky plánovaný na Ústavu pozemních komunikací je uveden v následující kapitole 3 Popis současného stavu.

Prvním a zároveň nejpodobnějším typem modelu je model z Georgia Institute of Technology, který simuluje zatížení na vozovce, přičemž měří svislé napětí ve vrstvách. Tento model však využívá pouze statického zatížení a nesimuluje tak prejezd vozidel a dynamickou odezvu souvrství [2].

Dalším poměrně shodným modelem je model od vědců z Harbin Institute of Technology v Číně, kteří pomocí tohoto modelu měřili deformace na třech základních typech povrchů - cementovém betonu, cementem stmeleném kamenivu a asfaltovém betonu. Jedná se však pouze o zatěžování jedné vrstvy a tento model nesimuloval celou skladbu vozovky. [3]

Třetí a nejrozšířenější skupinou "modelů" vozovky jsou pak naprríklad: ALF - Accelerated Loading Facility (Austrálie), HVS - Heavy Vehicle Simulator a APT - Accelerated Pavement Testing (USA) nebo MMLS - Model Mobile Load Simulator (Švýcarsko). Většinou se jedná o mobilní zatěžovací zatížení, složené z nosné konstrukce a jedné či více zatěžovacích pneumatik. Tyto pneumatiky simulují přejezd TNV a vyvozují zatížení na vybraný zkušební úsek. Jedná se bud' o lineární pohyb jedné pneumatiky dopředu a zpět, popř. o využití více pneumatik pohybujících se opakovaně za sebou. Př́klady těchto zařízení jsou zobrazeny na obrázcích - Obr. 1 Heavy Vehicle Simulator a Obr. 2 Mobile Load Simulator MLS10 [4], [5].

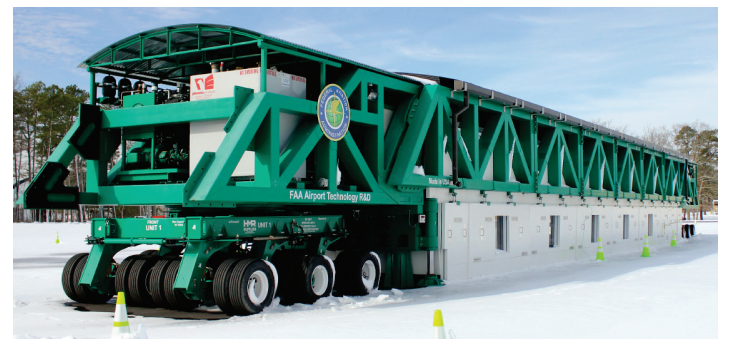

Obr. 1 Heavy Vehicle Simulator [4].

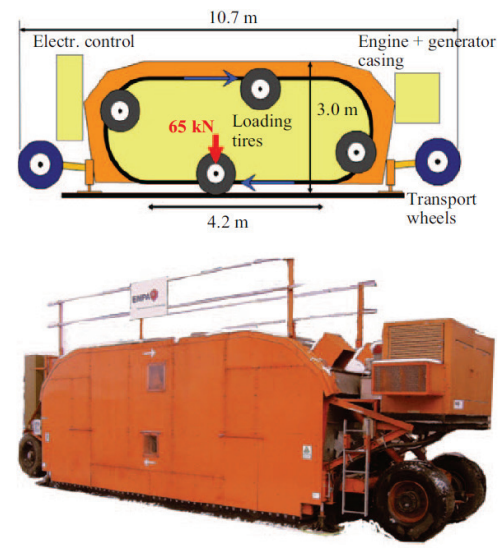

Obr. 2 Mobile Load Simulator MLS10 [5]. 


\section{POPIS SOUČASNÉHO STAVU}

\section{Popis Full-Scale modelu na Ústavu pozemních komunikací (ÚPKO)}

Pro pochopení problematiky je nutné si nejprve vysvětlit, co to je Full-Scale model vozovky a na jaké účely má být používán. Jedná se o zkušební zařízení složené z kovových přepážek, které dohromady tvoří krychli o rozměrech cca $1,8 \times 1,8 \times 2,0 \mathrm{~m}$. V tomto nadzemním kvádru (v některých případech může jít o podzemní jámu), se nacházejí jednotlivé vrstvy, stejně jako v konstrukci vozovky. Spodní část tvoří hlinité podloží o mocnosti $0,8 \mathrm{~m}$, na které navazuje spodní podkladní vrstva, tvořená štěrkodrtí Š $\mathrm{D}_{\mathrm{A}} 0 / 32 \mathrm{v}$ tloušt'ce $0,25 \mathrm{~m}$. Pokud není kladen požadavek na zkoušení speciálního typu podloží, zůstávají tyto vrstvy modelu neměnné. Další vrstvy se mohou měnit, dle typu zkoušené vozovky. V případě zkoušení tzv. referenční vozovky, je model dále tvořen př́islušnými vrstvami uvedenými obvykle v katalogu vozovek v dodatku TP 170. Takto vytvořená vozovka by měla být zatěžována hydraulickým lisem se zatěžovací deskou o průměru $30 \mathrm{~cm}$. Lis by měl model zatěžovat silou odpovídající přejezdu průměrného těžkého nákladního vozidla (TNV), přičemž zatěžovací křivka bude navržena tak, aby simulovala přejezd pěti samostatných náprav. Frekvence zatěžování by měla být v čase zvyšována, a to až do maximální hodnoty, odpovídající počtu přejezdo̊ TNV pro danou tř́ídu dopravního zatížení (TDZ) dle dodatku TP 170. Výše popsaný Full-Scale model vozovky, který se nachází v laboratoři Ústavu pozemních komunikací VUT FAST, a který je aktuálně ve fázi výstavby, je zobrazen na obrázku níže - Obr. 3.

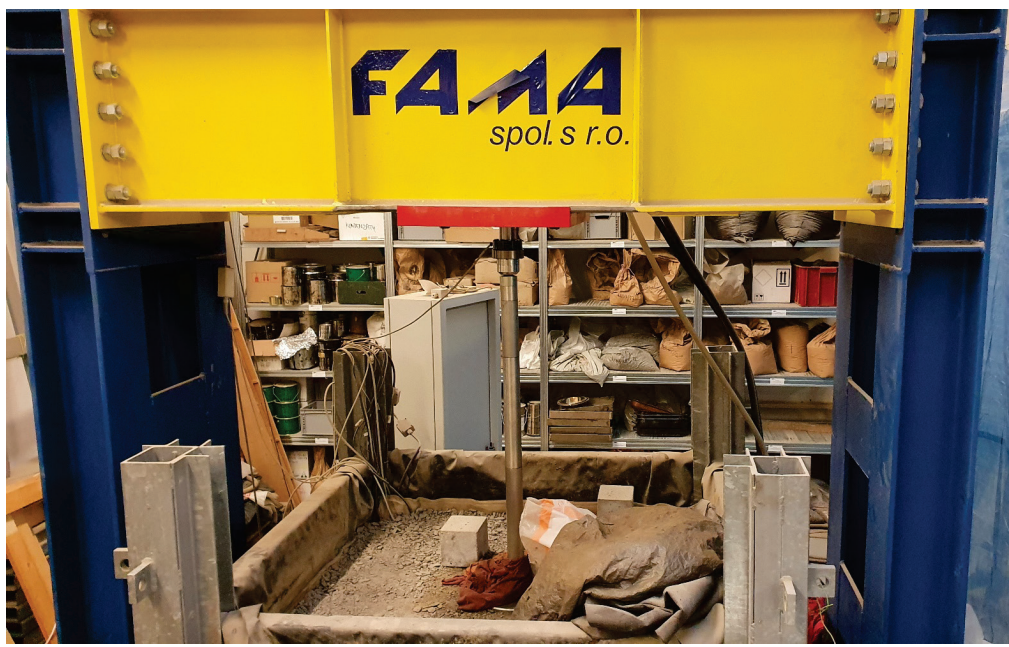

Obr. 3 Full-Scale model vozovky ÚPKO.

\section{Využití Full-Scale modelu (ÚPKO) pro zkoušení recyklovaných vozovek}

Jak již bylo uvedeno v úvodu článku a v předchozích kapitolách, daný model zatím není plně funkční a pracuje se na jeho zprovoznění. Jedním z důvodů jeho zprovoznění byl právě zvyšující se zájem o používání recyklátů a nových technologií a jejich komplexní zkoušení. A právě zvyšujícímu se zájmu o recyklované materiály nasvědčují mnohé práce prováděné v současnosti na Ústavu pozemních komunikací. Stručný přehled vybraných prací z posledních let je uveden v následujících odrážkách.

Diplomové práce:

- Charakteristické vlastnosti směsných recyklátů pro spodní stavbu pozemních komunikací [6]

- Směsný recyklát do podloží vozovek pozemních komunikací [7]

- Využití asfaltových a betonových recyklátů do pozemních komunikací [8]

- Dávkování oživovacích přísad do asfaltové směsi s vysokým obsahem R-materiálu [9]

- Inovativní asfaltové směsi pro obrusné vrstvy s použitím vyššího množství R-materiálu [10]

\section{Disertační práce:}

- Recyklace asfaltových pojiv pomocí oživovacích prrísad [11]

- Použití R-materiálu do asfaltových směsí typu asfaltový koberec mastixový [12] 
Většina z těchto prací se zabývá zkoušením jednotlivých vrstev, respektive recyklovaných materiálů použitelných do konstrukcí vozovek. Na těchto materiálech jsou sice převážně provedeny př́slušné funkční či empirické zkoušky, ale dlouhodobé účinky a celkové ověření chování těchto materiálů a vrstev v reálných podmínkách vozovkového souvrství chybí. A právě díky Full-Scale modelu bude možné, obdobně jako u zkušebního úseku, avšak za jednodušších podmínek v laboratorním prostředí, zkoušet právě toto chování a vzájemné reakce mezi jednotlivými vrstvami.

Výhodou Full-Scale modelu je pak jeho "snadné a rychlé" sestavení a operativní možnost změny složení konstrukčních vrstev bez dalších omezujících faktorů, na rozdíl od zkušebních úseků v reálném prostoru. U těchto úseků mohou nastat problémy týkající se např.: aktuální klimatické situace (nelze pokládat konstrukční vrstvy), nefungujících obaloven asfaltových směsí (v zimních měsících), omezení provozu při výstavbě a potřeba většího množství mechanizace apod. Zároveň je u těchto úseků složité ovlivnit aktuální zatížení působící na danou konstrukci.

Většina z výše uvedených vlivů u Full-Scale modelu nenastává, avšak některá řešení mohou být pro přesnou simulaci skutečného stavu obtížněji proveditelná. O tomto tématu je dále pojednáváno v diskusi.

Ve Full-Scale modelu tak bude možné zkoušet jak nerecyklované vozovky, tak vozovky složené z kombinace vrstev recyklovaných a vrstev ze surových materiálů, tak celorecyklované vozovky. Hlavním př́nosem bude tedy především zjištění vzájemného působení vrstev jako uceleného prvku, a ne pouze jako samostatných nespolupůsobících entit.

\section{Instrumentace modelu}

Kapitola instrumentace modelu popisuje předpokládané základní vybavení Full-Scale modelu vozovky měřicími přístroji a čidly, která by měla sloužit k zaznamenávání základních veličin popisujících fungování modelu. Rozmístění jednotlivých čidel vychází z výzkumů a článků v zahraniční literatuře.

V modelu je plánováno umístění teplotních čidel na povrchu krytové asfaltové vrstvy, uprostřed asfaltového souvrství a na jeho spodním líci. Dále se předpokládá umístění minimálně po jednom teplotním čidle na každém rozhraní vrstev, popř. ve středu každé vrstvy. Díky tomu bude možné podrobně popsat vývoj teploty po celém svislém profilu vozovkového souvrství.

Dalším plánovaným typem čidel jsou tlakoměrné krabice, které by měly snímat vertikální napětí v podloží a v jednotlivých podkladních vrstvách. Př́iklad takového čidla je zobrazen na obrázku - Obr. 4.

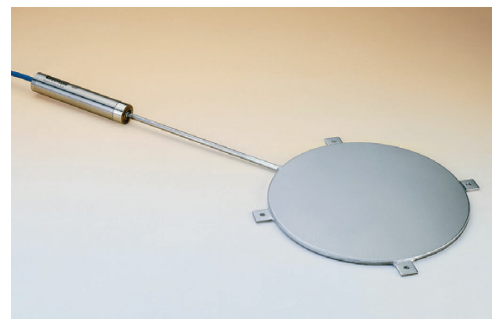

Obr. 4 Př́iklad tlakoměrné krabice pro snímání vertikálního napětí [13].

Třetím typem čidel by měly být speciálně upravené snímače horizontálního přetvoření, které jsou schopny odolávat vysokým teplotám při pokládce asfaltových směsí. Tato čidla se umist'ují právě do asfaltových vrstev, a to jak do obrusné (horní), tak podkladní (spodní) asfaltové vrstvy. Vzhledem k rotační symetrii Full-Scale modelu není nutné měřit napětí ve více než v jednom horizontálním směru, na rozdíl od zkušebních úseků v terénu. Př́íklad takového snímače je uveden na obrázku Obr. 5 [15], [16], [17], [18].

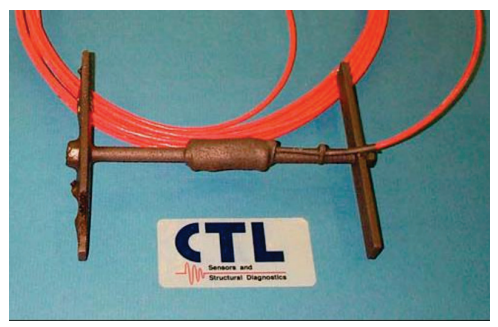

Obr. 5 Př́iklad horizontálního snímače přetvoření do asfaltové směsi [14]. 
Prozatím posledním plánovaným čidlem je vlhkoměr pro snímání vlhkosti v podloží vozovky. Toto čidlo by mohlo být použito v pozdějším výzkumu, kdy by docházelo k simulaci zavodňování a opětovnému odvodňování podloží.

Pro lepší pochopení rozložení napětí a přetvoření ve vrstvách vozovky a s tím související rozmístění čidel, je na obrázku - Obr. 6 - zobrazen zjednodušený příklad chování běžného vozovkového souvrství při zatížení.

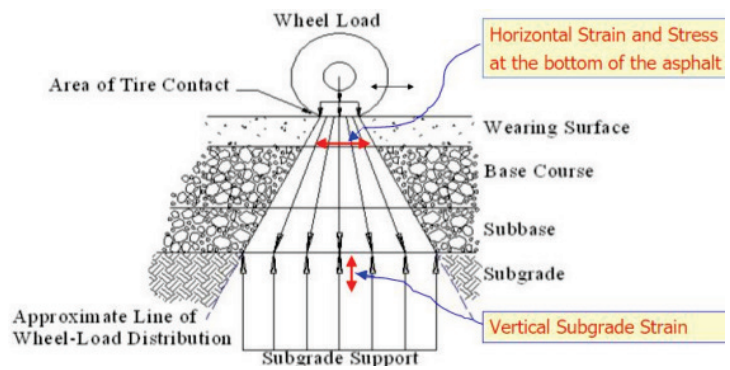

Obr. 6 Rozložení napětí od zatížení ve vozovce [19].

\section{DISKUZE}

Jak již bylo uvedeno v předchozích kapitolách, Full-Scale model vozovky může poměrně kvalitně sloužit ke zkoumání reálného chování vozovkového souvrství, a to poměrně snadno v laboratorních podmínkách, bez nutnosti výstavby zkušebního úseku. Je ale zcela jasné, že i přes mnohá pozitiva se jedná pouze o zjednodušený model, který nemůže plně nahradit zkoušení reálné vozovky. Proto jsou v následujících odstavcích uvedena pozitiva i negativa, a s nimi se pojící další plánovaný výzkum, kterým bude možné daný Full-Scale model přiblížit více realitě.

V samém začátku výzkumu je plánováno vytvoření základního, běžně používaného souvrství - typu ACO/SMA 11 S, ACL 16/22 S, ACP 22 S, MZK a ŠD (D0-N-1), na němž bude model ověřen a zkalibrován. Vyvozované zatížení bude $\mathrm{v}$ několika cyklech zvyšováno až na, případně za maximální hranici $\mathrm{TNV}_{\mathrm{k}}$. V začátku bude osazeno pouze několik teplotních, deformačních a napět'ových čidel, která budou dle potřeby doplňována. Veškeré skladby budou ze začátku zkoušeny a porovnávány pouze při konstantní, předem zvolené teplotě. $\mathrm{K}$ tomuto kroku je prozatím přistoupeno $\mathrm{z}$ důvodu absence dostatečně výkonného chladicího aparátu.

V následujících letech je plánováno rozšiřování a zpřesňování zkušebního modelu. Mohlo by dojít k nahrazení zatěžovací desky zkušební dvounápravou s pneumatikou, zavedení simulace klimatických podmínek za pomocí chladící/vyhřívací komory a kropení povrchu vodou. Jednou z mnoha dalších možností rozvoje Full-Scale modelu je simulace stoupání hladiny podzemní vody zatápěním podloží vozovky vodou. V neposlední řadě pak můžou být ve zkušebním zařizení zkoušeny nejen samostatné vrstvy, ale např. i spolupůsobení výztužných sítí do asfaltových vrstev či různých geosyntetik.

\section{ZÁV̌̌R}

Jak již bylo uvedeno $\mathrm{v}$ předchozích kapitolách, Full-Scale model vozovky může simulovat zatěžování vozovkového souvrství, ověřovat jeho chování, a to jak vizuálně, tak pomocí naměřených hodnot. V kombinaci s vhodně zvolenými funkčními a empirickými zkouškami jednotlivých vrstev a materiálů, lze získat poměrně přesný obraz o fungování dané vozovky, respektive její porovnání s odpovídající, předem ozkoušenou vozovkou z katalogu vozovek. Na rozdíl od zkušebního úseku "in situ", dokáže model poměrně snadno reagovat na změnu parametrů kladených na model, at’ už se jedná o složení vrstev nebo úroveň, druh a četnost zatěžování.

Závěrem je vhodné uvést, že Full-Scale model na Ústavu pozemních komunikací je stále v začátcích své existence, a proto je tento článek spíše stručným shrnutím dané problematiky a plánů dalšího výzkumu. Důvodem pro jeho zprovoznění je mimo jiné právě narůstající množství nových recyklovaných materiálů, a z toho plynoucí řada inovativních vozovkových vrstev, jejichž "funkcionalitu" ve skladbě vozovek nelze vždy ověrit nebo vyvrátit pouze pomocí aktuálně dostupných zkoušek.

Cílem tedy aktuálně není pouze měřit hodnoty napětí a deformací a popisovat jejich rozdělní v daném souvrství, ale zejména vzájemně porovnávat a posuzovat tyto "nové typy vozovek" s běžně používanými vozovkami, a to nejen pomocí naměřených parametrů, ale také i vizuální kontrolou, popř. provedením navazujících zkoušek na porušených vrstvách. 


\section{Použité zdroje}

[1] ČESKÁ REPUBLIKA, 2010. TP 170 Navrhování vozovek pozemních komunikací - dodatek. In: . Praha: Ministerstvo dopravy, odbor silniční infrastruktury, čj. 682/10-910-IPK/1. Dostupné také z: http://www.pjpk.cz/data/USR_001_2_8_TP/TP_170_Dodatek_1.pdf

[2] SOWERS, George a Aleksander VESIC, 1962 . Vertical Stresses in Subgrades Beneath Statically Loaded Flexible Pavements [online]. Washington DC [cit. 2021-11-25]. Dostupné z: https://onlinepubs.trb.org/Onlinepubs/hrbbulletin/342/342-005.pdf. Př́spěvek na konferenci. Georgia Institute of Technology

[3] Xingye Zhou, Xudong Wang, "A Large-Scale Test Method for Mechanical Response of Pavement Structure", Advances in Materials Science and Engineering, vol. 2018, Article ID 2642409, 12 pages, 2018. https://doi.org/10.1155/2018/2642409

[4] Dynatest: Heavy Vehicle Simulator [online], 2021. Ballerup (Denmark): Dynatest [cit. 2021-11-25]. Dostupné z: https://dynatest.com/equipment/heavy-vehicle-simulator/

[5] Partl, Manfred \& Raab, Christiane \& Arraigada, M.. (2015). Innovative asphalt research using accelerated pavement testing. Journal of Marine Science and Technology (Taiwan). 23. 269-280. 10.6119/JMST014-0326-1.

[6] Bc. Lumír Junek Charakteristické vlastnosti směsných recyklátů pro spodní stavbu pozemních komunikací. Brno, 2021. 106 s., 9 s. př́l. Diplomová práce. Vysoké učení technické v Brně, Fakulta stavební, Ústav pozemních komunikací. Vedoucí práce doc. Ing. Dušan Stehlík, Ph.D.

[7] Bc. Daniel Masař Směsný recyklát do podloží vozovek pozemních komunikací. Brno, 2020. 118 s., 3 s. př́l. Diplomová práce. Vysoké učení technické v Brně, Fakulta stavební, Ústav pozemních komunikací. Vedoucí práce doc. Ing. Dušan Stehlík, Ph.D.

[8] Bc. Zbyněk Žd'ára Využití asfaltových a betonových recyklátů do pozemních komunikací. Brno, 2020. 129 s., 129 s. příl. Diplomová práce. Vysoké učení technické v Brně, Fakulta stavební, Ústav pozemních komunikací. Vedoucí práce doc. Ing. Dušan Stehlík, Ph.D.

[9] Bc. Markéta Čumíčková Dávkování oživovacích prrísad do asfaltové směsi s vysokým obsahem Rmateriálu. Brno, 2018. 115 s. Diplomová práce. Vysoké učení technické v Brně, Fakulta stavební, Ústav pozemních komunikací. Vedoucí práce Ing. Ondřej Dašek, Ph.D.

[10] Bc. Karel Spies Inovativní asfaltové směsi pro obrusné vrstvy s použitím vyššího množství R-materiálu. Brno, 2020. 81 s., 31 s. příl. Diplomová práce. Vysoké učení technické v Brně, Fakulta stavební, Ústav pozemních komunikací. Vedoucí práce Ing. Pavel Šperka

[11] KOUDELKA, Tomáš. Recyklace asfaltových pojiv pomocí oživovacích přísad. Brno, 2020, 204 s., 17 s. příloh. Disertační práce, Vysoké učení technické v Brně, Fakulta stavební, Ústav pozemních komunikací, Vedoucí práce Doc. Dr. Ing. Michal Varaus.

[12] COUFALÍKOVÁ, Iva. Použití R-materiálu do asfaltových směsí typu asfaltový koberec mastixový. Brno, 2019. 160 s., 12 s. příl. Disertační práce. Vysoké učení technické v Brně, Fakulta stavební, Ústav pozemních komunikací. Vedoucí práce Ing. Petr Hýzl, Ph.D.

[13] Pressure Cell Model 4800, c2021. GEOKON: Trusted Measurements [online]. Lebanon (USA): GEOKON [cit. 2021-11-25]. Dostupné z: https://www.geokon.com/4800

[14] Asphalt Embedded Strain Transducers (LE, TE, AE), c2021. Minnesota Department of Transportation [online]. St. Paul (Minnesota): Minnesota Department of Transportation [cit. 2021-11-25]. Dostupné z: https://www.dot.state.mn.us/mnroad/data/files/sensorlocations/dynamic/asphalt-embedded-straintranscucers-le-te-ae-2020-august.pdf

[15] LAJNEF, Nizar. Smart Pavement Monitoring System [online]. 2013, 150 [cit. 2021-11-25]. FHWAHRT-12-072. Dostupné z: https://www.fhwa.dot.gov/publications/research/infrastructure/pavements/12072/12072.pdf

[16] PRECISION TRANSDUCERS for Measuring Strain and Stress in Pavements, c2021. Dynatest [online]. Ballerup (Denmark): Dynatest, c2020 [cit. 2021-11-25]. Dostupné z: https://dynatest.com/wpcontent/uploads/2021/06/PAST-1.pdf

[17] TIMM, David, Angela PRIEST a Thomas McEWEN. Design and Instrumentation of the Structural Pavement Experiment at the NCAT Test Track [online]. In: . 2004, s. 89 [cit. 2021-11-25]. NCAT Report 04-01. Dostupné z: https:/www.eng.auburn.edu/research/centers/ncat/files/technicalreports/rep04-01.pdf

[18] AST \& VAST | ASPHALT STRAIN TRANSDUCERS, c2020. BDI [online]. Louisville (USA): BDI, c2020 [cit. 2021-11-25]. Dostupné z: https://bditest.com/wp-content/uploads/2020/08/DatasheetAsphalt-Strain-Transducer-AST350-208601-Rev-A.pdf

[19] KRISTJÁNSDÓTTIR, Rut, 2017. Design of Heavy Duty Pavements [online]. Stockholm (Švédsko), 59 s. [cit. 2021-11-25]. ISSN 0349-5752. Dostupné z: https://www.diva-portal.org/smash/get/diva2: 1161068/FULLTEXT01.pdf. Disertace. KTH Royal Institute of Technology. 